\title{
BASIC MOTION VERBS IN NYAKYUSA: LEXICAL SEMANTICS AND ASSOCIATED MOTION
}

\author{
Bastian Persohn \\ University of the Free State / University of Cologne
}

\begin{abstract}
This paper gives a descriptive account of the lexical semantics of seven basic verbs of translational motion in Nyakyusa (Bantu, M31), together with a description of the meaning and use of another motion verb that has grammaticalized to a marker of associated motion. The findings include, among other things, that Nyakyusa's most simple verb of motion encodes solely a motion path and that only the 'come'-verb, but none of the 'go'-verbs, encodes reference to the deictic centre. Applying a microcomparative perspective, the choice of 'go'-verb that has grammaticalized to a marker of associated motion is explained based on the relative salience assigned to the goal vis-àvis the path.
\end{abstract}

Keywords: Nyakyusa, Bantu, semantics, motion

\section{Introduction}

1.1 Translational motion in Bantu. ${ }^{1}$ The aim of this paper is to give a detailed description of the lexical semantics of seven basic verbs of translational motion in Nyakyusa M31, ${ }^{2}$ a Bantu language of Tanzania, together with a note on some of their extended uses. Translational motion is understood as involving the movement of a figure (the moving object) along a motion trajectory, which may or may not be delimited by landmarks such as a source (the initial location) or a goal (the final location). Any verb that denotes manner of motion or a more complex trajectory such as a return path (a path leading back to some original location) is excluded. The analysis of the lexical verbs of translational motion is complemented by a discussion of a former verb of translational motion that has grammaticalized as a marker of associated motion (a grammatical device that serves to portray an act against the background of a motion co-event; see $\S 4$ ).

The need for a detailed description of the lexical semantics of motion verbs is made prominent by Wilkins \& Hill's (1995) seminal work. These authors point out that "verbs that depict come and go scenes cross-linguistically vary in their base semantics to such a degree that there is no useful sense in which they may be considered universal notions" (Wilkinson \& Hill 1995: 124). Also, Dimmendaal (2000: 191-1992) states that there has so far been little study made of patterns of lexicalization in African languages. As for the Bantu language family, some patterns of lexicalization of motion are discussed in Gaines (2001), albeit with focus on Talmy's typology of verb-framed vs. satellite-framed languages; see below on the latter. Sitoe (2001) is a book-length study of motion verbs in Changana S53, including the effects of derivation and a discussion of

1 The author wishes to thank Maud Devos for her insightful comments on earlier versions of this paper, the anonymous reviewers for their very helpful comments and Marcia Wadham for proofreading. The usual disclaimer applies. Research on Nyakyusa was made possible through funding from the a.r.t.e.s. Graduate School for the Humanities Cologne.

2 Combinations of a letter plus digits following the name of a language indicate the code the language receives in the updated version of Guthrie's referential system (Maho 2009). 
inflectional morphemes grammaticalized from motion verbs. Botne (2005) gives a detailed description of lexical semantics and the construction of complex motion events in Ndali M301. As Ndali is closely related to Nyakyusa, the present study allows us to observe patterns of microvariation. Botne (2006) discusses the motion scheme of various 'come' and 'go' verbs across a number of Bantu languages from the background of grammaticalization. Devos (2014) is a detailed examination of 9 basic motion verbs in Shangaci P312. Lastly, some Swahili G42, Nyakyusa and data from other Bantu languages are discussed by Lusekelo (2010). Some of his analysis of Nyakyusa, however, does not hold up to further scrutiny, and he does not discuss the associated motion marker (j)a 'go'. A first approach to the latter is found in Persohn 2017a (pp. 317-320). The present study thus contributes to broadening our understanding of the encoding of motion in Bantu languages.

The remainder of this study is structured as follows: In $\S 1.2$, the semantic components of motion verbs are discussed, to then give some background information on the Nyakyusa language $(§ 1.3)$. This is followed by a discussion of locative expressions in Nyakyusa ( $(1.4)$ and the structure of the verb in this language $(\S 1.5)$. In $\S 1.6$, data collection is described. $\S \S 2-4$ form the main body of this study. In $\$ 2$, the only deictic verb among Nyakyusa's basic verbs of, isa 'come', is described, and in $\S 3$ six non-deictic basic verbs of motion are examined. $\S 4$ contains a discussion of the grammaticalized auxiliary $(j) a$ 'go'. The article concludes in $\S 5$.

1.2 Analysing motion verbs. In typological studies of motion verbs (Talmy 1985, Wilkins \& Hill 1995, among others), the following components are normally understood as essential for the description of translational motion:

1. an anchor (source or goal of the motion)

2. the direction in relation to the anchor(s)

3. a description of the motion path

4. the relation of the motion to a deictic centre

Botne (2005) proposes two additional components: coincidence between the motion figure and an anchor and the relative salience of an anchor vs. the path. In $\S 3.4$ we will critically discuss the first (coincidence). The latter (relative salience) has most likely played a role in grammaticalization in Nyakyusa $(\S 4)$.

Concerning the question of deixis, Wilkins \& Hill (1995: 125) warn against assuming that a verb in a given language that translates as 'go' is necessarily deictic: "there are languages in which the GO verb is not inherently deictic”. In $\S \S 3$ and 4 we will see that Nyakyusa is such a language.

Basic or translational motion events can also be associated with a description of the manner of motion. In a well-known typology proposed by Talmy (2000), languages are classified as either 'verb-framed' or 'satellite-framed', based on how they conflate motion, direction and manner respectively (but see Slobin 2004, among others). Verb-framed languages are said to conflate motion and direction while expressing manner in a separate syntactic element. Satellite-framed languages, on the other hand, are said to conflate manner and motion, while expressing direction in 'satellites', e.g. affixes, particles, adpositions or case markers. Within this typology, Bantu languages are commonly described as predominantly verb-framed (Schaefer \& Gaines 1997; Gaines 2001), although some uses of applicative morphemes can be understood as representing an additional satellite-framed pattern (Beavers et al. 2010; also see Seidel 2007). 
1.3 Nyakyusa. Nyakyusa (M31) is a Bantu language of south-western Tanzania, spoken on the coastal plains of Lake Nyassa and in the hills to the north of it (e.g. Wilson 1963: 1). The number of speakers lies between 730,000 and 1,080,000 (Muzale \& Rugemalira 2008; Simons \& Fedding 2017). Its closest relatives are Ndali (M301), bordering to the west, and Ngonde (M31d) across the Malawian border.

1.4 Locative expressions. The linguistic construal of motion events typically includes locative expressions. These therefore deserve a short discussion. Nyakyusa has three locative noun classes. Table 1 lists the shape of the locative prefixes and a short summary of the meaning of each class. See Gregoire (1975) on locatives from a pan-Bantu perspective.

Table 1: Locative noun classes

\begin{tabular}{lll}
\hline \hline Class & Prefix & Semantics \\
\hline 16 & $p a-$ & 'at', 'proximity' \\
17 & $k \mho-$ & 'general area', 'far away' \\
18 & $m u$-(typically N / C C) & 'in' \\
\hline \hline
\end{tabular}

Locations are also often indexed on verbs through enclitic demonstratives of the shapes $=p o$ (class $16),=k o$ (class 17) and =mo (class 18). While Nyakyusa also uses object prefixes for the locative noun classes, their use is very rare (see Persohn 2017b). In some contexts, verbs of motion may be used without any overt locative expression. This will be addressed at various points in the discussion of specific lexical verbs.

As for the functional role of locative expressions, Creissels (2006: 23) observes that especially in the Niger-Congo phylum, to which the Bantu languages belong, "locative expressions [...] by themselves provide no clue to the choice between the roles of localization, source or destination. Localization is the default interpretation, and the roles of source or destination can be assigned by verbs only."

1.5 Verb structure. Verbs in Nyakyusa have the highly agglutinative structure that is typical of Bantu languages. The following is a slightly simplified version of the linear structure of the inflected verbal word:

\section{(1) Tense $=$ Subject-NEG/TAM-Object-Root-Derivation-TAM=LOC/WH}

As the different motion verbs in Nyakyusa contribute different components of a motion event, the description of a complete motion episode normally requires the use of more than one verb. This interplay of the various motion verbs will be addressed at various points throughout this article.

As for syntactic structure, the different verbs employed in a description of a motion event may either be finite verbs distributed across more than one clause (2), or alternatively, infinitival complements may be employed. This can either be in the form a bare infinitive, as in (3), or an infinitive together with an enclitic form of comitative ('with/and') na (4). Infinitives by themselves never express an anchor. They may, however, be additionally marked for one of the three locative classes, in which case class 16 indicates a specific place at which the event takes place, as with the last verb in (4). Classes 17 and 18 typically give a purpose reading, as in the last verb in (3) (also see Persohn 2017a: 327-328). 
(2)
a-fum-ile
ku-Manow
i-ku-bowka
ku-Ndembo
1-come_from-PFV
17(LOC)-M
1-PRS-go
17(LOC)-N.

' $\mathrm{S} / \mathrm{he}$ is going from Manow to Ndembo. [lit. has come from Manow ... is going to

Ndembo]'

(3)
ba-linku-bopa
a-ka-balılo
kala $\sim$ ka-la
ひ-kw-bowka
kv-kv-keeta
2-NARR-run
AUG-12-time
REDUPL 12-DIST
AUG-15(INF)-go
17(LOC)-15(INF)-watch
I-mi-gonda gy-abo
AUG-4-field 4-POSS.PL

'They ran off right away to look at their fields

(4)

\begin{tabular}{|c|c|c|c|}
\hline I-n-gwina & $\mathrm{j}$-iis-aga & $n-k v-j-e e g a$ & I-n-gambili \\
\hline AUG-9-crocodile & 9-PST.come-IPFV & 18(LOC)-15(INF)-9-take & AUG-9-monkey \\
\hline $\mathrm{n}=\boldsymbol{n}-\mathbf{k} \boldsymbol{-}-\mathbf{b} \boldsymbol{\prime} \mathbf{k a}$ & na $=$ jo & pa-lv-sungo & pa-kw-angala \\
\hline $\mathrm{COM}=\mathrm{AUG}-15(\mathrm{INF})-\mathrm{gc}$ & $\mathrm{COM}=\mathrm{REF} .9$ & 16(LOC)-11-island & 16(LOC)-15(INF)-be well \\
\hline
\end{tabular}

'Crocodile used to come to pick up monkey and go with him to an island to spend time together

1.6 Data collection. The data used in this study come primarily from two sources. First, ten scenes from Wilkins \& Hill's (1993) 'come' and 'go' questionnaire were elicited with two language assistants ('informants') each. The scenes used are listed in the appendix. These scenes depict the trajectory of a figure along a path, together with possible anchors and the deictic centre, the latter of which may or may not coincide with one of the anchors. As an example, scene 4 is given in (5).

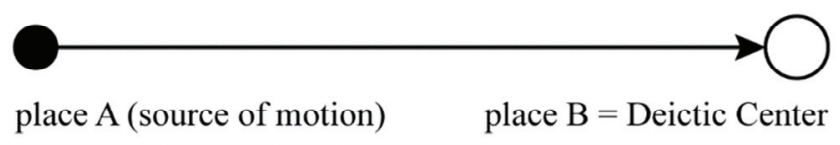

(5) Scene 4:

Elicitation of the questionnaire scenes was provided by giving an English description. In case of the scene depicted in (5), this would be "We are here in Lwangwa. Somebody is moving from Itete to us." The second main data source has been the examination of 42 texts, mainly folk narratives. Some of these texts stem from the author's original fieldwork, others are the product of literacy workshops by SIL International and were kindly made available by Helen Eaton. The written texts have been checked for a phonemic spelling in collaboration with the language assistants. An additional oral rendition of a folk narrative was made available by Knut Felberg. Some peculiar uses of motion verbs in the texts were further discussed in the elicitation sessions. Complementing the analysis of texts and questionnaires, some data from participant observation 
are also included. A few additional illustrative examples have been taken from a draft of a Bible translation by SIL International (kindly provided by Helen Eaton). ${ }^{3}$

Table 2 lists the 7 lexical verbs plus $(j) a$ 'go'- the latter is only available as an auxiliary in the present-day language - that are in the focus of this study, together with their Proto-Bantu reconstructions. For sooka 'leave' no suitable Proto-Bantu reconstruction is attested.

Table 2: Verbs in the focus of this study

\begin{tabular}{lll}
\hline \hline Nyakyusa & Gloss & Proto-Bantu (Bastin et al. 2003) \\
\hline bøvka & 'go' & *búok 'rise up; go away; fly away' \\
enda & 'travel' & *génd 'walk; travel; go; go away' \\
isa & 'come' & *jij 'come' \\
fuma & 'come from’ & *kúm 'come from' \\
fika & 'arrive, reach' & *pik 'arrive' \\
sooka & 'leave' & n/a \\
kında & 'pass' & *kínd 'throw in wrestling; overcome' \\
\hline (j)a & 'go' & *gì 'go' \\
\hline
\end{tabular}

In the following, first the only deictic verb among these verbs, namely isa, 'come' is discussed (§2), turning then to each of the remaining six non-deictic lexical motion verbs (§3). Lastly, in $\S 4$ the associated motion auxiliary $(j) a$ is discussed.

\section{Deictic motion: isa 'come'}

The only out of the eight verbs that explicitly encodes a deictic centre - by default the location of the speaker - is isa 'come'. Both language assistants used it in the description of scenes 4 and 5, the only scenes depicting motion of the figure to the location of the speaker. (6) corresponds to scene 4 .

$\begin{array}{llll}\text { i-kw-isa } & \text { a-pa } & \text { U-kU-fuma } & \text { kw-Itete } \\ \text { 1-PRS-come } & \text { AUG-PROX.16(LOC) } & \text { AUG-15(INF)-come_from } & \text { 17(LOC)-I. } \\ \text { 'S/he's coming here from Itete.' } & & \end{array}$

While isa lexicalizes reference to the deictic centre, it does not encode a landmark identifying the site of the deictic centre, i.e. a goal. Thus, while the location of the deictic centre may be identified, e.g. through apa 'here' in (6), isa is often found without any overt locative expression. Also note that both language assistants used isa in the description of scene 3, which encodes motion of a figure on a path towards, but not delimited by the deictic centre. Scene 3 is given in

\footnotetext{
${ }^{3}$ Scripture quotations from The Authorized (King James) Version. Rights in the Authorized Version in the United Kingdom are vested in the Crown. Reproduced by permission of the Crown's patentee,

Cambridge University Press,
} 
(7), and its description in (8). To make the termination of the motion event explicit, fika 'arrive' may be employed $(\$ 3.4)$

(7) Scene 3:

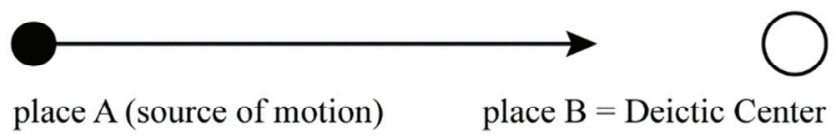

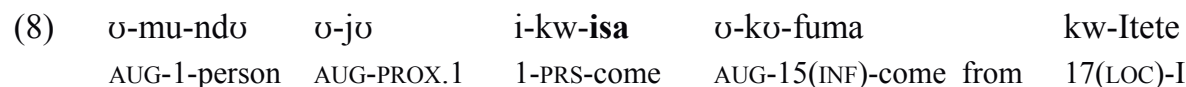

'This person is coming [towards us] from Itete.'

Not only does is not encode a goal, it also does not encode a source. To indicate the source of motion, a form of fuma 'come from' ( $\$ 3.3)$ needs to be used. If one removes the infinitival form of fuma plus complement in $(6,8)$, they correspond to scene 5 , which is given in (9). Botne (2005) makes the same observations for the cognate verb is a in neighbouring Ndali. To sum up, isa encodes unanchored motion along a path towards the deictic centre.

(9) Scene 5:

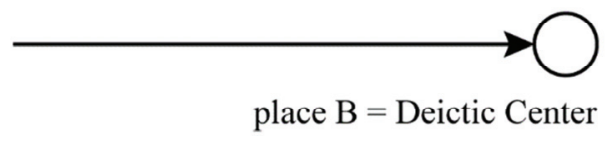

Apart from its original meaning as a motion verb, is a has also grammaticalized to a phasal verb (a.k.a. aspectual verb) which takes an infinitive without the augment ('pre-prefix') as its complement. In this function its meaning has undergone a metaphorical transfer (see Lichtenberk 1991: 487, among others) from denoting translational motion towards the deictic centre to denoting that the subject reaches, achieves or is led to a specific condition

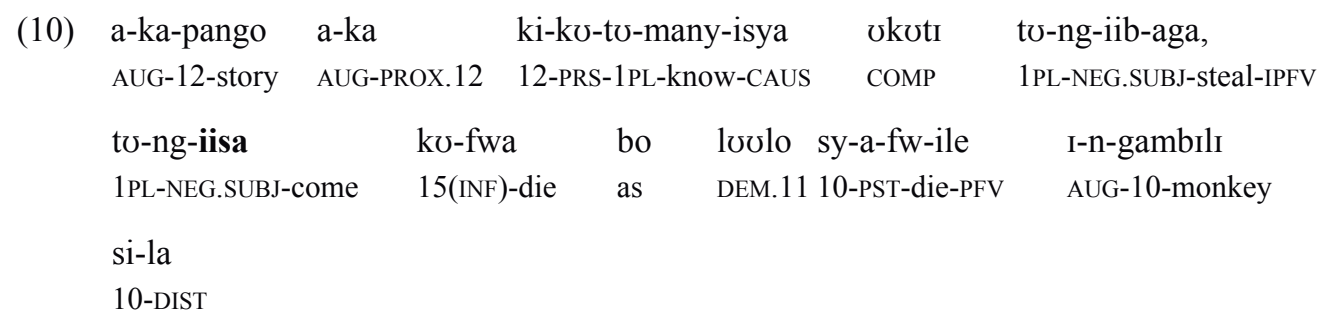

'This story teaches us that we should not steal, otherwise we will die (lit. we should not come to die) just like those monkeys died.' 
The simple present of is a has grammaticalized even further from this ingressive function to a marker of future time reference; see Persohn (2017a: 260-265, 320-322) for discussion.

\section{Non-deictic motion}

3.1 bovka 'go'. The verb bovka describes motion on a path that is delimited by a goal. It was consistently employed in the description of scenes 1,7 , and 14 , all of which describe motion to a goal. Scene 1 is illustrated in (11) and its description is given in (12).

(11) Scene 1:

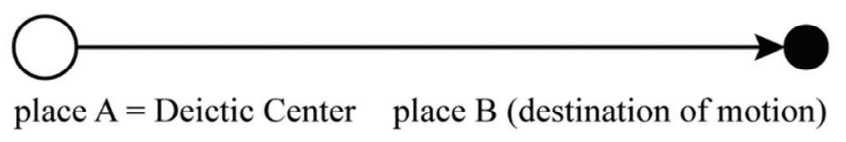

(12) i-kひ-bovka kw-Itete

1-PRS-go 17(LOC)-I.

'S/he is going to Itete.'

One language assistant also used bovka in the description of scene 13, which describes motion towards, but not to a goal:

(13) Scene 13:

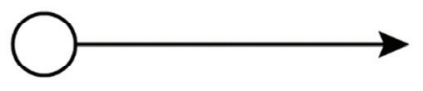

place $\mathrm{A}=$ Deictic Center place B (indeterminate if goal)

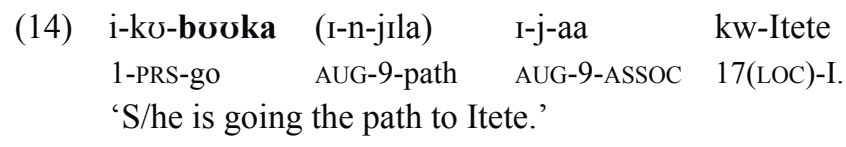

It is noteworthy that this language assistant did not use the goal (Itete) as the complement of bovka 'go', but circumscribed it by a noun phrase 'the path to Itete', thus effectively describing an anchored path. The second language assistant used a different verb, namely labila 'go in a certain direction' for the description of this scene.

In $\S 1.2$ it has been pointed out that 'go' verbs need not necessarily be deictic. This is corroborated by the Nyakyusa data. First, the source of the motion depicted by bovka need not be the deictic centre, as its employment in scenes 7 and 14 shows: in both scenes the motion leads away from the deictic centre but does not start there. So far, this could be interpreted as bovka denoting motion in a direction away from the deictic centre. An examination of data from texts shows that this is not necessarily the case. Consider (15), which stems from the beginning of a 
narrative. In this example, the figure (a certain man) moves a long an anchored path. The deictic centre here is the settlement on top of a mountain, which is also the goal.

(15) Context: Three people have built on top of a mountain.

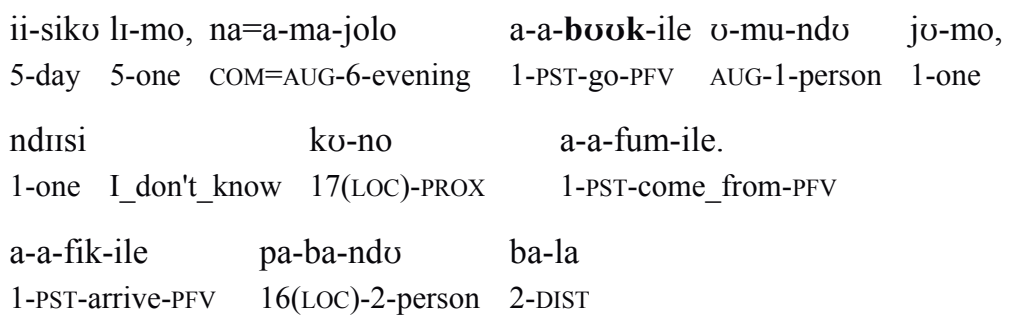

'One day in the evening, a certain person, I don't know where he came from, went. He arrived at those people's.'

In the same fashion in (16) the goal of motion, Lion's place, coincides with the place where the entire story takes place, hence the deictic centre.

(16) Context: Lion was ill. He slept for three days.

\begin{tabular}{|c|c|c|c|c|}
\hline leelo & ji-lınkv-lagıla & jI-linkv-tI & v-tu-nyamaana & $\mathrm{t}$-oosa \\
\hline then & 9-NARR-order & 9-NARR-say & AUG-12-animal & 12-all \\
\hline $\mathrm{k}$-iisu & ky-ake & tu-buひk-ege & $k v-k v-j I$ & eta \\
\hline 18(LOC)-7-land & 7-POSS.SG & 12-go-IPFV.SUB. & 17(LOC)-1 & (INF)-9-watch \\
\hline
\end{tabular}

'Then he [Lion] ordered that all little animals in his land should go to see him.'4

A deictic reading of bovka as motion away from the deictic centre can, however, arise contextually through opposition with the deictic verb isa 'come'. Such a case is given in (17). The second 'go' verb $(j) a$ that is employed in this example will be discussed in §4. (17) illustrates another interesting fact about the use of bovka in discourse: it may be used without the overt expression of a goal, which, however, remains implicit ('go to some place'). That is, unlike English go or Swahili G42 enda (TUKI 2014a; Anthon Mwangake, personal communication), Nyakyusa bovka without a locative complement does not express the notion of 'to leave'. The latter is expressed by the verb sooka $(\S 3.5)$.

4 The language assistants consulted prefer the masculine pronoun in the English translation here. 
(17) Context: Hare and Skunk are staying together.

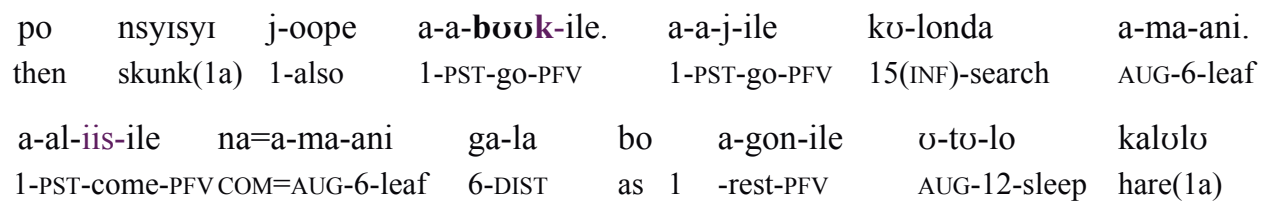

'Skunk also went. He went and searched for leaves. He came with those leaves, while Hare was asleep.'

To summarize, bovka denotes motion towards a goal. As (15-17) have shown, it does not include reference to the deictic centre as part of its meaning. Concerning these components, Nyakyusa bovka parallels its cognate buuka in neighbouring Ndali. In Ndali, the verb in question, however, forms part of a lexical opposition based on the relative salience assigned to the goal and path components respectively (Botne 2005). The meaning and function of Nyakyusa's grammaticalized 'go'-verb $(j) a$ indicate that this opposition could be found in earlier Nyakyusa chronolects, see $\S 4$.

3.2 enda 'travel'. The verb enda, for lack of a more adequate English translation is here glossed as 'travel'; it denotes unanchored motion along a path. In elicitation of the questionnaire, it was used only by one of the two language assistants, namely in the description of scenes 15 and 7 . Scene 15 describes motion of the figure along an unanchored path passing by the deictic centre (here the town of Lwangwa). Scene 15 is illustrated in (18) and its description is given in (19).

(18) Scene 15:

(19)
end-ile ku-Lwangwa
1.travel-PFV 17(LOC)-L.
'S/he has gone by Lwangwa.'

Discussing this use of enda in comparison to kInda 'pass' (\$3.6), the assistant explained that enda in this scenario merely describes the trajectory, whereas kInda makes explicit the fact of moving beyond the landmark (the town of Lwangwa). Accordingly, in the texts examined, any locative noun phrase accompanying enda is understood as describing (a part of) the trajectory, not a landmark. For instance, in (20), the locative noun phrase pamwanya pamyabo 'on top of them' describes a portion of the path along which the figure (the group of invaders) moves. 
(20) Context: Invaders have come. The locals have hidden below the hay.

$\begin{array}{lllll}\text { po } & \text { ba-linkw-enda } & \text { pa-mwanya } & \text { pa-my-abo. } & \text { ba-linkw-enda } \\ \text { then } & \text { 2-NARR-travel } & \text { 16(LOC)-high } & \text { 16(LOC)-4-POSS.PL } & \text { 2-NARR-travel }\end{array}$

$\begin{array}{lllll}\text { pa-my-abo } & \text { pa-ba-ndo } & \text { a-ba } & \text { b-iibırliile } & \text { paa-si } \\ \text { 16(LOC)-4-POSS.PL } & \text { 16(LOC)-2-person } & \text { AUG-PROX.2 } & \text { 2-hide_at.PFV } & \text { 16(LOC)-below }\end{array}$

'They [invaders] walked on top of them. They walked on top of the people that were hidden below.'

A closer look at scene 7, the other scene in which one language assistants employed enda, shows that the anchors, which differentiate this scene from scene 15, are introduced by fuma 'come from' and bovka 'go' respectively. This gives further evidence of the non-anchored semantics of enda. Scene 7 is given in (21) and its corresponding description in (22).

(21) Scene 7:

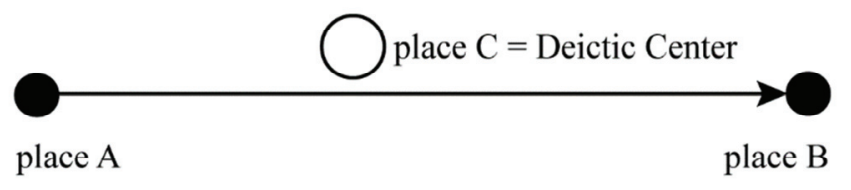

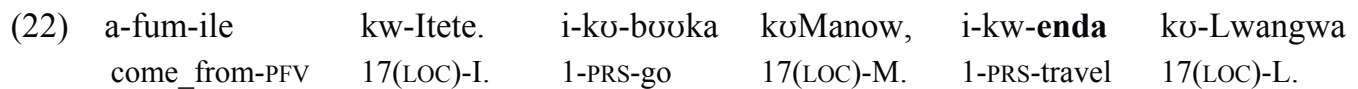
'S/he has come from Itete. $\mathrm{S} /$ he is going to Manow, s/he is passing by Lwangwa.'

Lusekelo (2010) states that "manner of motion is indicated [...] by Nyakyusa enda 'walk' [...] the verb encodes manner of motion". While 'walk' is indeed often a suitable translation for enda, the following examples will show that manner is not part of the lexical semantics of this verb.

(23) Context: Crocodile is travelling with monkey on his back.

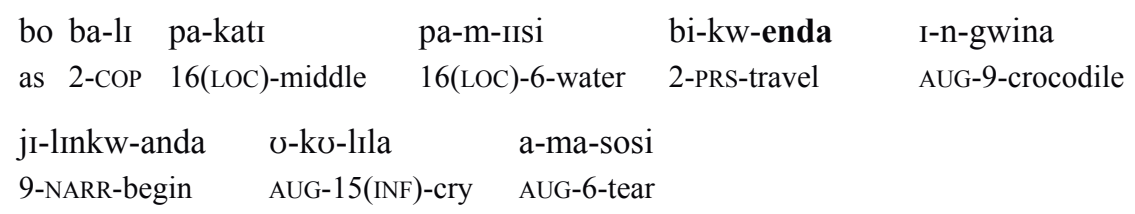

'When they were travelling in the middle of the water, Crocodile started to cry.'

Even though we are dealing with a fable and hence with anthropomorphized animals, the locative noun phrase pakat pamissi 'in the middle of the water' excludes any interpretation of enda as depicting manner of motion. Further evidence for enda encoding a path, but neither anchor nor manner, comes from its use to express abstract movement of things. In (24) it is the success of work that is portrayed as a trajectory, while in (25) it is the object of trade, potatoes, which is depicted as the figure that is changing location. In fact, enda is the default verb used to describe 
(metaphorical or physical) translational motion without reference to the deictic centre, anchor or manner.

$\begin{array}{llllll}\text { gi-ku-lond-igwa } & \text { a-ma-hala } & \text { m-ingi } & \text { fiijo linga } & \text { kU-londa } \\ \text { 6-PRS-need-PASS } & \text { AUG-6-wisdom } & \text { 6-many } & \text { INTENS } & \text { if/when } & \text { 2sG.PRS-want } \\ \text { I-m-bombo } & \text { sy-ako } & \text { sy-end-e } & \text { kanunu } & \\ \text { AUG-10-work } & \text { 10-POSS.2SG } & \text { 10-travel-suBJ } & \text { well }\end{array}$

'You must be very clever to be successful (lit. Very much intelligence is required if you want that your work goes well).'

(25) si-kw-enda bole pa-Mbeja?

10-PRS-travel how 16(LOC)-M.

'For what price (lit. how) do they [potatoes] go in Mbeya?'

To sum up, the Nyakyusa verb enda lexicalizes only a path, but neither the deictic centre nor anchor or manner of motion. Botne (2005), who observes the same for the cognate verb in Ndali points out that this verb thus presents a prime example of Miller \& Johnson-Laird's (1979) primitive verb TRAVEL.

As for non-motion functions, enda together with a comitative infinitive ( $n=v-k w$ - ' $\mathrm{COM}=\mathrm{AUG}$ 15(INF)-') serves as a marker of an ensuing development in narrative discourse (26) (Persohn 2017a: 330).

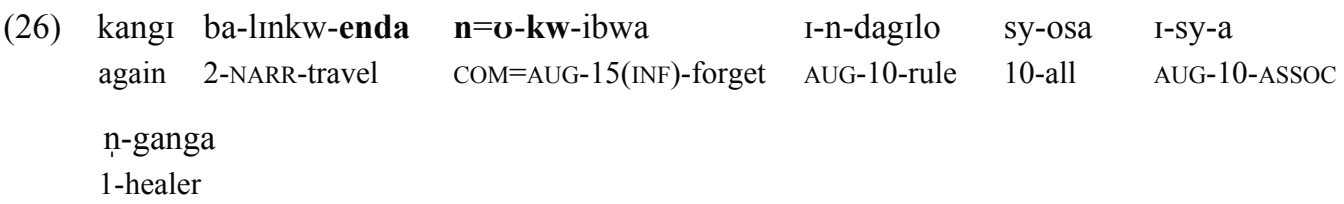

'Then they forget all the rules of the witch doctor.'

Lastly, enda together with the intensive extension (-elela), which by itself denotes repetition, intensity or continuity of an act (Persohn 2017a: 100-101), serves as a phasal verb ('aspectual verb') denoting the continuation or resumption of an act (27).
(27) ju-la a-linkw-end-elela $\quad$-kv-mm-ongesya $\quad$-mw-ana
1-DIST 1-NARR-travel-INTS AUG-15(INF)-1-breastfeed AUG-1-child

'That one continued to breastfeed the child.'

3.3 fuma 'come from'. The verb fuma depicts motion away from a source. It was consistently used by both language assistants in the description of scenes 3, 4, 6, 7 and 14, all of which include motion away from a landmark. (28) illustrates scene 14, (29) gives the corresponding description. 
(28) Scene 14:

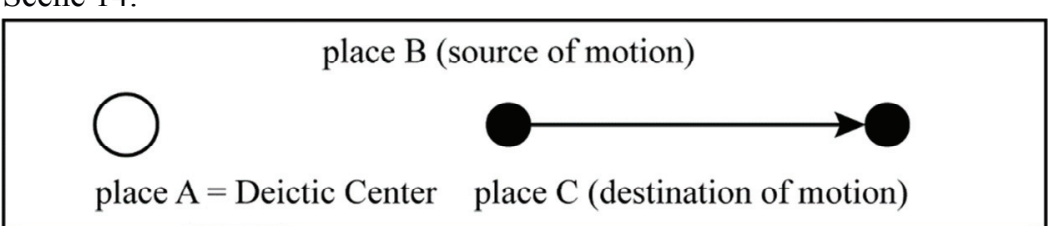

(29)

\begin{tabular}{|c|c|}
\hline e & p-Iitete, i-ku-buvka \\
\hline
\end{tabular}

'S/he is going from Itete to Masoko.'

Like for the verb enda, the data on fuma clearly indicate that this verb is not inherently deictic. In scene 14 (ex. 29), the source of motion is a landmark distinct from the deictic centre, while at the same time the motion leads away from the deictic centre. In scenes 3, 4, 6 and 7, on the other hand, motion takes place in the direction of the deictic centre, or passing by it; see (6) above for scene 4 (Ikwisa apa vkvfuma kwItete). Unlike what Botne (2005: 56-57) reports for its Ndali cognate, Nyakyusa fuma is not attested in the data with a sense of motion away from the inside of a source. To give a meaning of 'get out of', sooka is employed (\$3.5).

To sum up, fuma denotes motion of the figure away from a source. It does not encode the deictic centre as part of its meaning. Note that neighbouring Ndali (Botne 2005), unlike Nyakyusa, distinguishes between two verbs with this meaning, which differ in the relative salience they assign to the source and path component.

Lastly, Nyakyusa fuma is also used to indicate not the source of motion, but the home of a person (30). In a related fashion, the infinitive ( $v$ )kofuma is also used in a preposition-like manner, in which it indicates a source location outside of motion eventualities (31). As a metaphorical extension, this may even be a temporal starting point (32); a similar development of sourceoriented motion verbs is found in other Bantu languages, for instance with Swahili G42 toka 'get out, go out/leave, exit' (TUKI 2014b).

kひ-fuma kuvgo?
2sG.PRS-come_from where?
'Where are you from?'

$\begin{array}{lllll}\text { a-a-ba-koliile } & \text { a-ba-anaake } & \text { bo } & \text { ba-bili } & \boldsymbol{\sigma} \text {-ko-fuma } \\ \text { 1-PST-2-call.PFV } & \text { AUG-2-his_child } & \text { REF.2 } & \text { 2-two } & \text { AUG-15(INF)-come_from } \\ \text { kU-tw-aja } & \text { tw-abo } & & & \\ \text { 17-13-homestead } & \text { 13-POSS.PL } & & & \end{array}$

'He called his two children from their villages.'

$\begin{array}{lllll}\text { bひ-mmw-ag-ile } & \mho-b \mho-b i n e & \mho-b \mho & \boldsymbol{\sigma}-\mathbf{k} \mho-f u m a & \text { ndilli? } \\ \text { 14-1-find-PFV } & \text { AUG-14-sickness } & \text { AUG-PROX.14 } & \text { AUG-15(INF)-come_from } & \text { when } \\ \text { 'How long is it ago since this [illness] came unto him?' (Mark 9:21) } & \end{array}$


3.4 fika 'arrive, reach'. The Nyakyusa verb fika, as its cognate Ndali counterpart (Botne 2005: 66) is not attested in the questionnaire data, but is very frequent in discourse, where it marks the endpoint of a motion event. (33) is a first example.

\begin{tabular}{|c|c|c|c|c|c|}
\hline $\begin{array}{l}\text { po } \\
\text { then }\end{array}$ & $\begin{array}{l}\text { a-linkw-enda, } \\
\text { 1-NARR-travel }\end{array}$ & $\begin{array}{l}\text { a-linkw-enda } \\
\text { 1-NARR-travel }\end{array}$ & $\begin{array}{l}\text { a-lInkw-enda. } \\
\text { 1-NARR-travel }\end{array}$ & $\begin{array}{l}\text { a-linku-fika } \\
\text { 1-NARR-arrive }\end{array}$ & $\begin{array}{l}\text { pa-n-jIla } \\
\text { 16(LOC)-9-path }\end{array}$ \\
\hline$d-1 a$ & i-bilı & I-Si & si-paagu & & \\
\hline $16(\mathrm{LOC}$ & 10-two & AUG-PROX. & 10-branch o & RECP.PFV & \\
\hline
\end{tabular}

'She went, went, went. She arrived at that [place at the] path where the two paths separate.'

Botne (2005: 68) describes the cognate verb in Ndali as "encoding coincidence of figure and place $[\ldots]$ motion [...] latently implied". As for coincidence of figure and place, it is unclear how far the additional component of coincidence needs to be assumed for Nyakyusa. To begin with, the stipulation of coincidence as a separate component of motion verbs is embedded in his cognitive approach to semantics: Botne assumes an image-schematic semantic representation of the meaning of motion verbs and adopts Wilkinson \& Hill's (1993) representations of motion scene to "represent features of the lexical content of the individual verbs" (Botne 2005: 49). It is only within such an allegedly holistic cognitive schema approach that the representation of arrival (or its counterpart, departure) calls for an additional semantic component. Secondly, according to Botne (2005: 67) "-fika makes salient the coincidence of figure and goal". The notion of saliency is originally introduced by Botne (2005) to distinguish those Ndali verbs of motion whose meaning difference lies in the relative prominence of path vs. anchor (e.g. 'go TO' vs. 'GO to'; see $\S 4$ for Nyakyusa). In his discussion of 'arrive' and 'leave' verbs in Ndali, Botne, however, uses the term salient interchangeably with the explicit denotation of arrival and departure, which renders the notion of saliency mute.

Not adopting Botne's specific cognitive approach, we may simply assume that Nyakyusa fika encodes a change-of-state from motion to arrival at a goal (i.e. the explicit denotation of the goal as the endpoint of travel) as part of its lexical semantics. That being said, Nyakyusa fika has broader uses than English arrive. In the following example the speaker employs fika to denote that he should not only take to the road, but that he should reach his destination and be present at it.

(34) Context: An event of the presidential election campaign takes place at Lwangwa. The interlocutor wants to see the candidate's speech and therefore wants to finish the conversation.

m-fik-e pa-la
1sg-arrive-SUBJ $16($ LOC)-DIST
'I should arrive there.'

Use of fika is also attested with metaphorical movement of abstract entities, such as in the following example, where the moving figure is the abstract concept of hunger. 
(35)

$\begin{array}{llllll}\text { a-a-li } & \text { m-oolo } & \text { fiijo. } & \text { a-ka-al-iigan-ile } & \text { U-kU-bomba } & \text { I-m-bombo. } \\ \text { 1-PST-COP } & \text { 1-lazy } & \text { INTENS } & \text { 1-NEG-PST-like-PFV } & \text { AUG-15(INF)-work } & \text { AUG-9-work }\end{array}$

po kokuti ka-balılo I-n-jala j-aa-fik-aga pa-ka-aja

then every 12-time AUG-9-hunger 9-PST-arrive-IPFV 16(LOC)-12-homestead

ka-ake

16(LOC)-12-homestead 12-POSS.SG

'It [tortoise] was very lazy. It did not like to work. So constantly hunger reached its home.'

In concord with the denotation of the endpoint of a motion event, fika is frequently used in narratives in a discursive structure similar to tail-head-linkage, ${ }^{5}$ as illustrated in (36). The use of bovka in the first sentence denotes motion to a goal (the homestead), while fika in the temporal clause of the second sentence denotes the endpoint of notion, thus the termination of the motion event.

(36) Context: Hare and Skunk went hunting and have caught a guinea fowl.

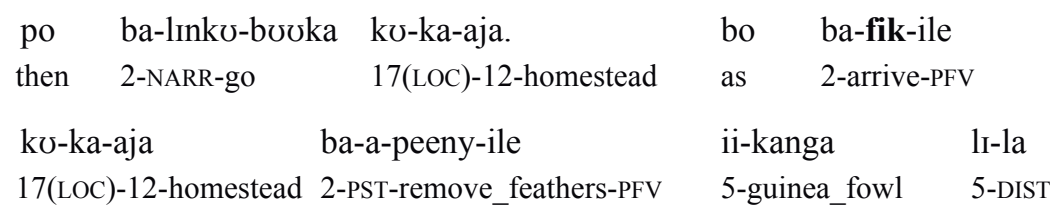

'They went home. When they arrived at home, they removed the feathers from that guinea fowl.'

Concerning the latency of the motion itself, as pointed out by Botne (2005) for the Ndali cognate of the verb in question, fika is typically used together with other motion verbs, as in (36). This distribution points to the fact that fika by itself does not denote a motion path. In cases where fika is used without further elaboration of a motion event, only the arrival is signalled explicitly, while the motion itself is suggested by context, such as in (35) above, or as in the following example.

(37) Context: Hare has left Spider behind to go and persuade Spider's fiancée to cancel the wedding.

\begin{tabular}{|c|c|c|c|c|c|}
\hline $\begin{array}{l}\text { kalvlo, } \\
\text { hare(1a) }\end{array}$ & $\begin{array}{l}\text { bo } \\
\text { as }\end{array}$ & $\begin{array}{l}\text { i-kv-joba } \\
\text { 1-PRS-speak }\end{array}$ & $\begin{array}{l}\text { n=U-n-kiikolo, } \\
\text { COM=AUG-1-woman }\end{array}$ & $\begin{array}{l}\mho \text {-lu-bubi } \\
\text { AUG-11-spider }\end{array}$ & $\begin{array}{l}\text { lv-linkひ-fika } \\
\text { 11-NARR-arrive }\end{array}$ \\
\hline
\end{tabular}

'As Hare was speaking with the woman, Spider arrived.'

As for the question of deixis, fika is attested in contexts where the goal equals the deictic centre, such as in (37), but also with goals other than the deictic centre, such as in (34). This distribution gives evidence that fika does not lexicalize reference to the deictic centre.

To sum up, the verb fika encodes a goal as the explicit endpoint of a motion event. It does not denote a motion path nor lexicalize reference to the deictic centre.

5 The term tail-head-linkage, coined by Thurmann (1975), refers to a discourse pattern in which the last clause of a chain is partially repeated at the beginning of the following clause. 
Lastly, the infinitive ( $v) k v f i k a$ is also used in a preposition-like manner, in which it can also denote a temporal endpoint:

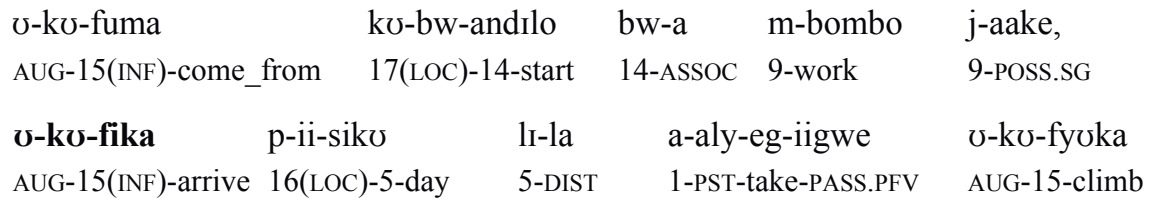

kv-mwanya

17-above

'[... of all that he] began both to do and teach until the day he was taken up [lit. from the beginning of his work until...]' (Acts 1: 1-2)

3.5 sooka 'leave'. The verb sooka is the counterpart to fika 'arrive'. In the questionnaire data it was used by one language assistant in the description of scene 1, and by both assistants in the description of scene 2. $(39,40)$ give scene 2 and its description.

(39) Scene 2:

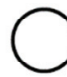

place $\mathrm{A}=$ Deictic Center

(40) i-ko-sooka=po

1-PRS-leave $=16$ (LOC)

'S/he is leaving'

While in (40) the source corresponds to the deictic centre, in the following extract from a narrative the action takes place in the main room of a house, while the source, from which the figure (the husband) departs, is another room. The motion can thus be understood as directed towards the deictic centre.

(41) Context: A married couple has set a trap for a strange woman, with the husband hiding in the bedroom.

\begin{tabular}{|c|c|c|c|}
\hline v-n-dume & a-linku-sooka & v-kv-fuma & kvo-sofu \\
\hline AUG-1-husband & 1-NARR-leave & AUG-15(INF)-come_from & $17(\mathrm{LOC})-\operatorname{room}(9)$ \\
\hline $\mathrm{n}=\mathrm{n}-\mathrm{k} U-\mathrm{n}-\mathrm{kola}$ & & - -n-kiikvlv ju-la & \\
\hline $\mathrm{COM}=\mathrm{AUG}-15(\mathrm{IN}$ & 1-grasp/hold & AUG-1-woman 1-DIST & \\
\hline
\end{tabular}

'The husband came out of the bedroom and caught that woman.' 
Example (41) illustrates another important point about sooka: in all attested tokens, when a path is expressed an additional verb of motion is used. As becomes evident from this distribution, sooka by itself denotes only separation from a source, but not a path.

In (40), sooka is used together with an enclitic form of the substitutive ('referential demonstrative') of locative noun class 16. In fact, sooka is frequently used with one of the enclitics of locative classes 16-18, which in this case specify the spatial relation to the source in accordance with the respective locative noun class semantics (42); see $\S 1.4$ on the latter and Persohn 2017b for a general discussion of post-finals in Nyakyusa.
(42) class 16: sooka=po 'go away; go off; pull out (train, bus)'
class 17: sooka=ko 'get away'
class 18: sooka $=m o$ 'get out'

The following example illustrates the use of sooka together with class $18=m o$ in discourse.
(43) bo ba-fik-ile kw-a
as 2-arrive-PFV 17(LOC)-ASSOC J. 2-NARR-1-see AUG-1-person
ju-la, $\quad$-ju $\quad$ si-sook-ile $=\mathbf{m o} \quad$ I-m-bepo $\quad$ II-nyali,
1-DIST 1-PROX 10-leave-PFV=18(LOC) AUG-10-spirit AUG-dirty(10)
a-torgeele kIfuki na Jesu
1-sit.PFV near COM J.
'[...] and came to Jesus [lit., when they had come to J.], and found the man, out of whom the devils were departed [lit. the ones the bad spirits had left from within], sitting at the feet of Jesus' (Luke 8: 35)

While the use of sooka with a locative enclitic is very frequent, (44) illustrates that the verb can also be used without an enclitic or any other overt locative expression.
(44)
po a-ka-balilo
then
kala ka-la
a-a-sook-ile
v-mu-ndv.
REDUPL 12-DIST
1-PST-leave-PFV
AUG-1-person
a-aly-omiilwe a-m-IIsi
1-PST-be_thirsty_for.PFV AUG -6-water
'That time, a person set off. He was thirsty for water.'

To sum up, sooka denotes separation of the figure from a source without encoding a motion path. It does not encode the deictic centre, and the spatial relation to the goal is often expressed through a post-final locative enclitic.

3.6 kinda 'pass'. The verb kInda encodes motion on a path beyond a landmark. In the questionnaire, it was employed in the descriptions of scenes 7 and 15, in which the landmark corresponds to the deictic centre. A look at the uses in texts reveals that kinda also allows for other landmarks. Thus in (45), the landmark beyond which the figure (the first child) moves is a snake blocking the way. 
(45) Context: A snake blocks the way. Children sing to pass it.

$\begin{array}{llllll}\text { gw-a } & \text { kw-anda } & \text { a-a-t-ile } & \text { <song> } & \text { a-a-kind-ile } & \text { U-mw-ana } \\ \text { 1-ASSOC } & \text { 15(INF)-start } & \text { 1-PST-say-PFV } & & \text { 1-PST-pass-PFV } & \text { AUG-1-child } \\ \text { jo-la } & & & & \\ \text { 1-DIST } & & & & \end{array}$

'The first one said: <song>. That child passed.'

The verb kInda on its own is not attested together with noun phrases denoting an anchor (source or goal). In those instances, in which the anchors are included in the description of the motion event, these are introduced by other verbs. Thus in (46), a rendition of scene 7 (also see $\S 3.2$ ), the source and the goal are introduced by fuma and bovka respectively. This gives evidence for kında denoting unanchored notion.

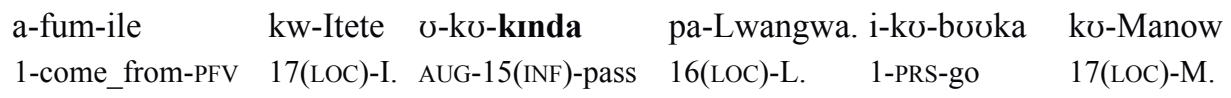

' $\mathrm{S} /$ he has come from Itete and is passing by Lwangwa. $\mathrm{S} /$ he is going to Manow.'

To sum up, kinda denotes unanchored, non-deictic motion on a path beyond a landmark. Apart from its use as a verb of motion, kinda is also used in comparisons of inequality, following a common pattern in Bantu languages and African languages in general (cf. Stassen 2013).

$\begin{array}{lllll}\text { a-linkw-aga } & \text { n-dali } & \text { J-kU-kında } & \text { mu-no } & \text { sy-a-j-IIl-iile } \\ \text { 1-NARR-find } & \text { 10-long } & \text { AUG-15(INF)-pass } & \text { 18(LOC)-PROX } & \text { 10-PST-be(come)-APPL-PFV } \\ \text { 'He found they [ears] were longer than they had been.' }\end{array}$

\section{Associated motion}

In this section, we discuss a grammaticalized verb of motion: $(j) a$ 'go'. The consonantal phoneme is given in brackets, as it is regularly dropped when following any prefix of the shape ko- (the infinitive, simple present and narrative tense), yielding the sequence $k w a$. (j) $a$ clearly goes back to Proto-Bantu *gì-a, with loss of stem-initial *g being a frequent phenomenon throughout the Nyakyusa lexicon. The cognate of $(j) a$ in neighbouring Ndali has the shape $y a$ which points to * gìa [uia] > [ya], and a comparison with Ndali phonology shows that at an earlier stage of Nyakyusa [y] became strengthened to [f].

Unlike in Ndali (Botne 2005), in Nyakyusa (j)a 'go' does not exist as a lexical verb. ${ }^{6}$ Instead, it has grammaticalized to an auxiliary that takes an infinitive without the augment ('pre-prefix') as its complement; it does not appear in any other morphosyntactic frame. See $(49,50)$ below for first illustrative examples. As to its function, $(j) a$ serves as a marker of associated motion. As this

6 There is, however, a copula of the shape ja, which also often loses its consonantal segment, albeit in different environments. 
grammatical category is still relatively unknown in studies of Bantu languages, ${ }^{7}$ it deserves a short excursion.

The term associated motion has been coined by Koch (1984) for certain verbal affixes in Kaytej, an Australian language from the Pama-Nyungan family, and has most commonly been used in treatments of Australian languages and languages from the Americas (Guillaume 2013, 2016; Koch 1984; Wilkins 1991, 2006) and of some African languages outside of Bantu (see Belkadi 2016). Associated motion markers serve as a grammaticalized way of expressing motion, more specifically to portray the act encoded in the verb stem with respect to a motion co-event (Wilkins 1991, 2006). For instance, in the Eastern Arrernte example (48), the act of dying is elaborated upon by framing it against a preceding co-event of running off through the use of yene'go and'.

(48) Eastern Arrernte (Pama-Nyungan, Australia)

nhartepe artnpe-nke, nhartepe ampwarre-yene-nke

then run-PRS then die-go_and-PRS

'Then it (the wounded animal) runs off and dies' (Wilkins 2006: 27)

Unlike what is found in Nyakyusa, canonical systems of associated motion typically use verbal affixes rather than auxiliaries and encode a wider array of distinctions, such as direction, the temporal ordering between motion main event, aspectual notions, and the identity of the moving entity (see Guillaume 2016 for an overview).

The motion co-event denoted by Nyakyusa $(j) a$ typically precedes the act encoded in the verb stem $(49,50) .{ }^{8}$ In a few instances, in all of which the lexical verb is a motion verb, the two events may be understood as concurrent rather than ordered; see (53) below for such a case.

(49) Context: the researcher is on his way 'home' from Manow mission. Halfway greetings are exchanged.

ひ-j-ile kv-bomba?

2SG-go-PFV 15(INF)-work

'Did you go (and) work?'

7 The relevant grammatical constructions are sometimes discussed under labels such as itive and ventive (e.g. Nurse 2008: 22), movement grams (Nicolle 2002; Persohn 2017a), distal aspects (Nicolle 2003), or deictic markers (Sitoe 2001). A typologically oriented examination of the encoding of associated motion across Bantu languages is the subject of ongoing research.

8 A preliminary description of $(j) a$, without a discussion of the category of associated motion, nor an elaboration of the questions of deixis and grammaticalization, is given in Persohn (2017a: 317-320). 
(50) Context: Speaking of marriage in old times.

\begin{tabular}{|c|c|c|c|c|c|}
\hline $\begin{array}{l}\text { linga } \\
\text { if/when }\end{array}$ & $\begin{array}{l}\text { a-ba-buvl-ile } \\
\text { 1-2-tell-PFV }\end{array}$ & $\begin{array}{l}\text { a-ba-paapi } \\
\text { AUG-2-paren }\end{array}$ & $\begin{array}{l}\text { ba-ake } \\
\text { 2-POSS.Sc }\end{array}$ & $\begin{aligned} & \text { pamo } \\
\text { SG } & \text { or }\end{aligned}$ & \\
\hline U-gwise & gw-a & n-domyana & ju-la, a & a-a-j-aga & \\
\hline AUG-his/her_father(1 & 1a) 1-ASSOC & 1-boy & 1 -DIST 1 & 1-PST-go-IPI & \\
\hline ku-n-sưm-Ila & ku-gwise & & $w-a$ & n-kiikølu & vkvtı \\
\hline 15(INF)-1-beg-APPL 1 & 17(LOC)-his/he & r_father(1a) & -ASSOC & 1-woman & СОMP \\
\hline nw- & n-go-londa & vkuti & -ege & & $\mathrm{n}=\mho$-mw-anang ${ }^{\prime \prime}$ \\
\hline UG-1-your_child 1 & 1SG-PRS-want & COMP $1 . \mathrm{m}$ & ry-PASS-IPF & FV.SUBJ & $\mathrm{COM}=\mathrm{AUG}-1-\mathrm{my}$ _child \\
\hline
\end{tabular}

'When he had told his parents or his father, he [father] would go to the woman's father and ask "Your child, I want it to be married to my child.""

As with bovka 'go', the question arises, whether the meaning of $(j) a$ includes any reference to the deictic centre. The context of (49) above shows that the source of motion need not be the deictic centre. This does, however, not exclude the possibility that $(j) a$ denotes an act that takes place at a location other than the deictic centre. The employment of $(j) a$ in examples such as (51) speak against such an interpretation: The story from which the excerpt in (51) is taken centres around a family's house. The protagonist, Python, is hidden in a banana tree outside the house. If we assume that the deictic centre, and hence the goal of the motion event, is the house, while the banana tree serves as a side stage, then we are dealing with motion towards the deictic centre. Alternatively, we may assume that the entire homestead, including the banana tree, constitutes the deictic centre. In this case we are dealing with motion within the deictic centre. In both interpretations, $(j) a$ clearly does not denote that the act encoded in the lexical verb takes place away from the deictic centre.

\begin{tabular}{|c|c|c|c|c|c|}
\hline po & j-aa-tI & "niine & n-gu-buðka bo & $a-k a-j a=p o$ & maama \\
\hline then & 9-SUBSEC-say & COM.1SG & 1SG-PRS-go & 1-NEG-be $($ come $)=16($ LOC $)$ & mother(1a) \\
\hline - & bo & ji-bovk-ile & II-sota & j-aa-j-ile & kw-Imba \\
\hline -DIST & then & 9-go-PFV & AUG-python(9) & 9-PST-go-PFV & 15(INF)-sing \\
\hline
\end{tabular}

'Then it [python] said: "Me too, I'm going when that woman isn't there." When python had gone it (went and) sang.'

The use of $(j) a$ is a frequent device in discourse. As a noteworthy fact, $(j) a$ does not always introduce a motion event of its own. Rather, as in (51), it often follows verbs such as bovka 'go' and thus echoes a preceding motion event. Likewise, in (52), (j)a does not introduce a second motion event. Instead, the act of searching takes place in the bushes, the goal of preceding bovka.

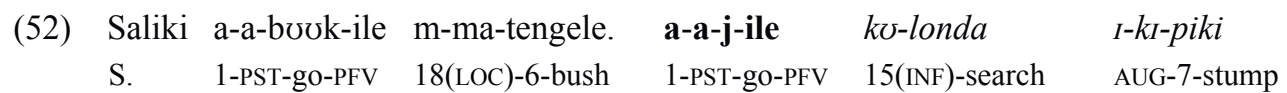
'Saliki went into the bushes. He (went and) searched for a stump.' 
This seeming redundancy is typical for associated motion markers. Similar observations have been made for geographically and genetically unrelated languages (Wilkins 1991, 2006; Guillaume 2009, among others). Wilkins (1991) in his discussion of the complex system of associated motion affixes in Eastern Arrernte explains this type of employment on a functional basis:

\begin{abstract}
It is important to remember that it is not the main function of 'associated motion' forms to present and elaborate information about a motion event [...] [T]he 'category of associated motion' functions to locate events within the flow of space [...] to foreground, identify and characterise the event in the verb stem [...] with respect to a particular motion event (Wilkins 1991: 251)
\end{abstract}

In narratives, $(j) a$ is frequently used in collocation with fika 'arrive' following other verbs of motion, often enda 'travel'. In this use, (j)a apparently serves to set the event of arrival against the ground of the preceding journey:

\begin{tabular}{|c|c|c|c|c|}
\hline $\begin{array}{l}\text { boo=buno } \sim \text { b } \mho-\text { no } \\
\text { REF.14=REDUPL } \sim 14-\text { DEM }\end{array}$ & $\begin{array}{l}\text { ba-linkw-enda, } \\
\text { 2-NARR-travel }\end{array}$ & $\begin{array}{l}\text { ba-linkw-enda, } \\
\text { 2-NARR-travel }\end{array}$ & $\begin{array}{l}\text { ba-linkw-enda } \\
\text { 2-NARR-travel }\end{array}$ & \\
\hline $\mathrm{n}=\mathrm{v}-\mathrm{kw}$-enda. & ba-a-j-a & kv-fika & n-k-iisv & kI-mo \\
\hline $\mathrm{COM}=\mathrm{AUG}-15$ (INF)-travel & 2-SUBSEC-go & 15(INF)-arrive & 18(LOC)-7-land & 7-one \\
\hline
\end{tabular}

'Thus they travelled, travelled, travelled and travelled. Finally they arrived in some land.'

As discussed above, (j)a 'go' often follows the lexical verb bovka 'go'. (54) illustrates that (j)a can also take the infinitive of this verb as its complement. In this excerpt from a story, a woman is instructed that at a following branch-off she should not go down the path where a certain sound is heard. Through the use of $(j) a$, this second motion event is portrayed against the ground of the first motion event (the travel that leads to the branch-off).

(54) Context: A magic animal is giving instructions to a woman.

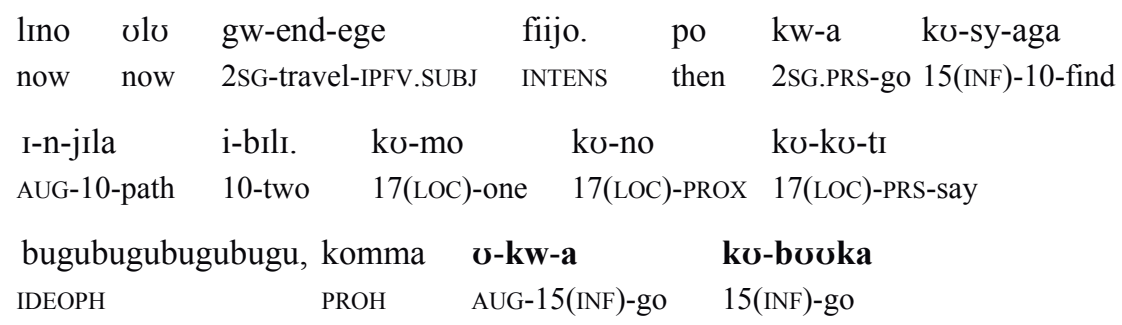

'Now walk much. You'll go and find two paths. At one, where it sounds bugubugu bugubugu, don't (go and) go there.'

As pointed out initially, the function of $(j) a$ lies in portraying the event encoded in the lexical verb against a motion co-event. Note at this point that Nyakyusa $(j) a$ does not have a motion-cumpurpose ('go in order to') reading. To give such a reading, bovka 'go' plus an infinitive marked additionally for either of locative noun classes 17 or 18 has to be used (55); also see (3). 


$\begin{array}{lll}\text { a-ba-nd } & \text { ba-a-bovk-ile } & \text { n-kv-n-keeta } \\ \text { AUG-2-person } & \text { 2-PST-go-PFV } & \text { 18(LOC)-15(INF)-watch }\end{array}$

'People went to see her.'

In the overwhelming majority of tokens, the entity that undergoes the motion co-event (i.e. the moving figure) is the same as the grammatical subject of $(j) a$. The only attested counter-example is the following excerpt from a narrative. Here we find two consecutive uses of $(j) a$. In the first, the speaker proposes to go and throw pepper at monkeys. In the second use, it is, to all appearances, not the grammatical subject of $(j) a$ (the monkeys) that moves. Instead the monkey's assumed reaction is portrayed against the previously introduced speaker's motion. It is likely that this use is motivated by the fact that the simple present of $(j) a$ often serves a future-oriented function (see below). It is worth foregrounding that no token of $(j) a$ is attested in which the figure of the motion co-event is the grammatical object.

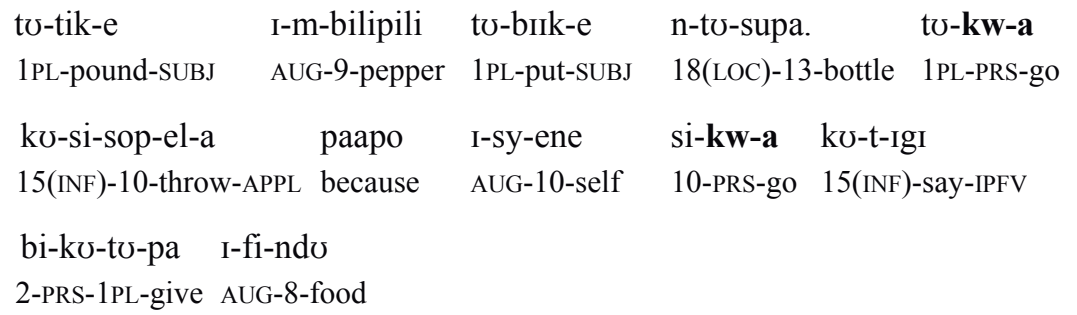

'We should pound pepper and put it in little bottles. Then we will go throw them at them, for they [monkeys] will think they [=we] are throwing food.'

To sum up, Nyakyusa ( $j) a$ has grammaticalized to an auxiliary that serves as a marker of associated motion. It denotes that an act is portrayed against the background of a - typically preceding - motion co-event and it does not encode any reference to the deictic centre.

A question that imposes itself at this stage is why (j)a 'go', but not bovka 'go', has grammaticalized to a marker of associated motion. A micro-comparative perspective offers an explanation. In neighbouring Ndali M301 both cognates of (j)a and bovka are used as lexical verbs. Botne (2006) shows that these two verbs differ in the relative salience they assign to the path and anchor respectively: Ndali ya emphasises the goal ('go TO'), whereas buuka emphasises the path ('GO to'). From a diachronic point of view, Botne's observation fits well with the reconstructed meanings of these two verbs in Proto-Bantu (Bastin et al. 2003): while *gì translates as simple 'go', the meaning of *bovk 'rise up; go away; fly away' suggests a stronger emphasis on the motion itself. A similar contrast of relative salience is also suggested by the definitions Schadeberg \& Mucanheia (2000) give for weetta and olawa in Koti P311, while Devos (2014) in a detailed examination of their cognate forms entta and lawa in Shangaci P312 comes to the same conclusion. Such a semantic distinction of saliency may thus well be a more widespread phenomenon in the Bantu-speaking area.

If we assume that at an earlier stage both Nyakyusa verbs $(j) a$ and bovka encoded the same distinction as their Ndali cognates, the current meaning of $(j) a$ can be understood as the result of an extension by which motion to a salient goal came to mean motion to a salient event (or, in Wilkin's terms, to denote the main event against the ground of the motion co-event). 
Lastly, note that the simple present of $(j) a$ has also developed a prospective (future-oriented aspectual) function (Persohn 2017: 258-260) and that a proclitic bare stem form $a a=$ serves as a "shifter" (Nurse 2008) that sets posterior or unrealized eventualities in a future frame of reference (see Persohn 2017a (250-255) for discussion of the latter.)

\section{Conclusion}

In $\S \S 2$ and 3, a detailed examination was given of the lexical semantics of 7 basic verbs of translational motion in Nyakyusa. Table 3 summarizes the findings.

As can be gathered from Table 3, Nyakyusa's most simple verb of translational motion is enda, which denotes unanchored, non-deictic motion along a path. Only one of the 7 basic motion verbs, is a 'come' encodes reference to the deictic centre. This gives further evidence for Wilkins \& Hill's (1995) observation that 'go'-verbs across languages need not necessarily be deictic. As Botne (2005) observes for the cognates of enda and isa in neighbouring Ndali, these two verbs of unanchored motion can be considered to form a primary lexical opposition, differing only in their (non-)deicticness. Nyakyusa's inventory of verbs of translational notion also includes bovka, which denotes motion to a goal as well as its mirror image fuma, which denotes motion away from a source. A pair of two further verbs, sooka and fika, leaves the motion itself latent, and encodes arrival at a goal and separation from a source respectively. In both cases the anchor is construed as the explicit starting point or endpoint of the motion event. Lastly, kinda denotes unanchored notion beyond a landmark. Along with the description of the lexical semantics of these verbs, some additional functions have been pointed out, such as e.g. the preposition-like uses of the infinitives of fuma and fika.

In comparison to its neighbour Ndali M301 (Botne 2005), Nyakyusa does not synchronically distinguish between verbs that differ in the relative salience they assign to the anchor vis-à-vis the path component. What is more, Nyakyusa has only one verb of motion beyond a landmark, whereas Ndali lexicalizes a two-way distinction between interrupted/non-interrupted and anchored/unanchored motion beyond a landmark. All this leads to a considerably smaller inventory of basic verbs of translational motion in Nyakyusa.

Table 3: Overview of lexical semantics

\begin{tabular}{|c|c|c|c|c|c|c|}
\hline Nyakyusa & Gloss & anchor & direction & path & deictic & further \\
\hline bovka & 'go' & goal & to goal & yes & no & l \\
\hline enda & 'travel' & l & l & yes & no & l \\
\hline$i s a$ & 'come' & l & towards deictic centre & yes & yes & / \\
\hline fuma & 'come from' & source & from source & yes & no & l \\
\hline fika & 'arrive, reach' & goal & to goal & no & no & endpoint \\
\hline sooka & 'leave' & source & from source & no & no & starting point \\
\hline kInda & 'pass' & / & / & yes & no & beyond landmark \\
\hline
\end{tabular}

In section $\S 4$, the verb $(j) a<$ Proto-Bantu * gì 'go' has been discussed. It has been shown that this Nyakyusa verb -which in the present-day language is found only as an auxiliary, and not as an 
independent verbal lexeme - serves as a marker of associated motion. In the clear majority of cases, it is the subject of $(j) a$ itself that undergoes translational motion. It has further been shown that the meaning of $(j) a$ includes no reference to the deictic centre. The grammaticalization of this verb has been explained by assuming that at an earlier stage Nyakyusa, like present-day Ndali (Botne 2005), distinguished two verbs of goal-oriented non-deictic motion, which differed in the relative saliency they assigned to the goal and motion path. The present-day meaning and function of Nyakyusa (j) $a$ can then be explained by a semantic shift in which a goal portrayed as salient vis-à-vis the motion path gave place to the denotation of an act profiled against the ground of a motion event.

The present study has contributed to our understanding of the lexicalization of motion in Bantu languages and has shown the fruitfulness of including a micro-comparative perspective to the subject matter. It has further given one of the first detailed examinations of a marker of associated motion in a Bantu language.

\section{Appendix}

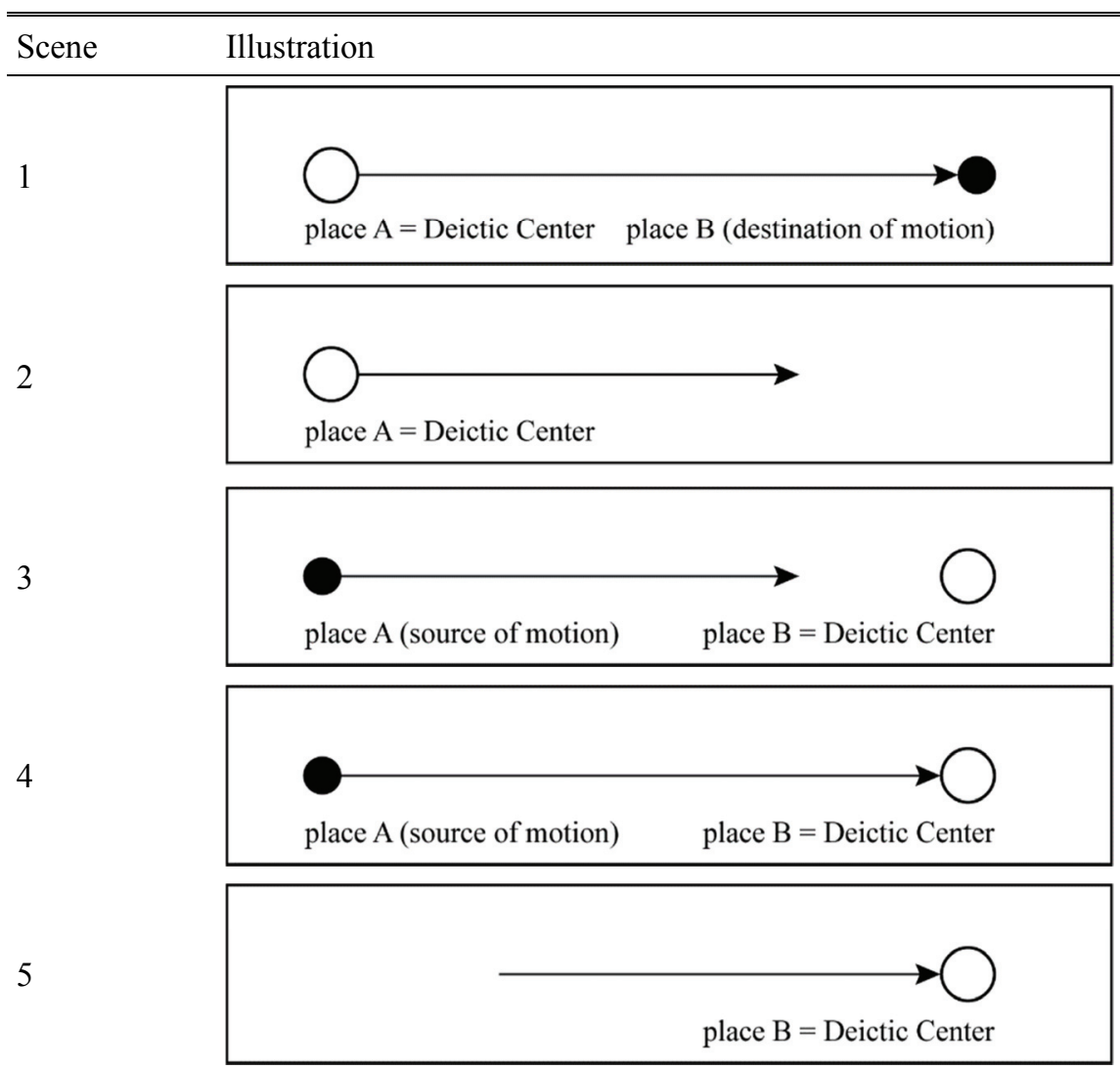




\begin{tabular}{|c|c|}
\hline Scene & Illustration \\
\hline 6 & place $\mathrm{A}$ (source of motion) $\quad$ place $\mathrm{C}=$ Deictic Center \\
\hline 7 & lace $\mathrm{C}=$ Deictic Center $\underset{\text { place } \mathrm{B}}{\longrightarrow}$ \\
\hline 13 & $\longrightarrow$ place $\mathrm{A}=$ Deictic Center \\
\hline 14 & $\bigcirc_{\text {place } \mathrm{A} \text { = Deictic Center }}^{\text {place } \mathrm{B} \text { (source of motion) } \mathrm{C} \text { (destination of motion) }}$ \\
\hline 15 & $\stackrel{\text { ace } \mathrm{C}=\text { Deictic Center }}{\longrightarrow}$ \\
\hline
\end{tabular}




\section{Abbreviations}

$\begin{array}{llll}1 \ldots 18 & \text { noun classes } & \text { NARR } & \text { narrative tense } \\ 1 \text { PL } & \text { first person plural } & \text { NEG } & \text { negative } \\ \text { 1SG } & \text { first person singular } & \text { PASS } & \text { passive } \\ 2 \text { SG } & \text { second person singular } & \text { PFV } & \text { perfective aspect } \\ \text { APPL } & \text { applicative } & \text { PL } & \text { plural } \\ \text { ASSOC } & \text { associative } & \text { POSS } & \text { possessive } \\ \text { AUG } & \text { augment } & \text { PROH } & \text { prohibitive } \\ \text { CAUS } & \text { causative } & \text { PROX } & \text { proximal demonstrative } \\ \text { COM } & \text { comitative } & \text { PRS } & \text { present tense } \\ \text { COMP } & \text { complementizer } & \text { PST } & \text { past tense } \\ \text { COP } & \text { copula } & \text { RECP } & \text { reciprocal } \\ \text { DEM } & \text { demonstrative } & \text { REDUPL } & \text { reduplication } \\ \text { DIST } & \text { distal demonstrative } & \text { SG } & \text { singular } \\ \text { IDEOPH } & \text { ideophone } & \text { SUBJ } & \text { subjunctive mood } \\ \text { INF } & \text { infinitive } & \text { SUBSEC } & \text { subsecutive } \\ \text { INTENS } & \text { intensifier } & \text { NARR } & \text { narrative tense } \\ \text { INTNS } & \text { intensive verbal extension } & \text { NEG } & \text { negative } \\ \text { IPFV } & \text { imperfective aspect } & \text { PASS } & \text { passive } \\ \text { LOC } & \text { locative } & \text { WH } & \text { wh-question marker }\end{array}$

\section{References}

Bastin, Yvonne, André Coupez, Evariste Mumba and Thilo C. Schadeberg. 2002. Bantu lexical reconstructions 3 / Reconstructions lexicales bantoues 3. http:/www.africamuseum.be/ collections/browsecollections/humansciences/blr (22 May, 2017).

Beavers, John, Beth Levin and Shiao Wei Tham. 2010. The typology of motion expressions revisited. Journal of Linguistics 46(2). 331- 377.

Belkadi, Aicha. 2016. Associated motion constructions in African languages. Africana Linguistica 22. 43-70.

Botne, Robert. 1999. Future and distal -ka-'s: proto-Bantu or nascent form(s)? In Larry M. Hyman and Jean-Marie Hombert (eds.), Bantu historical linguistics: theoretical and empirical perspectives, 473-515. Stanford: CSLI.

Botne, Robert. 2005. Cognitive schemas and motion verbs: coming and going in Chindali (eastern Bantu). Cognitive Linguistics 16(1). 43-80. 
Botne, Robert. 2006. Motion, time, and tense: on the grammaticalization of come and go to future markers in Bantu. Studies in African Linguistics 35(2). 127-188.

Botne, Robert. 2008. A grammatical sketch of Chindali (Malawian variety). Philadelphia: American Philosophical Society.

Creissels. Denis. 2006. Encoding the distinction between location, source and direction: a typological study. In Hickmann, Maya and Robert, Stéphane (eds.), Space in Languages. Linguistic Systems and Cognitive Categories, 19-28. Amsterdam: Benjamins.

Devos, Maud. 2014. Motion verbs in Shangaci: lexical semantics and discourse functions. In Devos, Maud and Jenneke van der Wal (eds.), 'come' and 'go' off the Beaten Grammaticalization Path. 281-318. Berlin: de Gruyter Mouton.

Dimmendaal, Gerrit J. 2011. Historical linguistics and the comparative study of African languages. Amsterdam: Benjamins.

Gaines, Richard. 2001. On the typology of directional verbs in Bantu. In Botne, Robert and Vondrasek, Rose (eds.), IULC Working Papers in Linguistics 3(1): Explorations in African Linguistics. 25-36. Bloomington: IULC Publications.

Grégoire C. 1975. Les locatifs en bantou. Tervuren: RMCA.

Guillaume, Antoine. 2009. Les suffixes verbaux de 'mouvement associé' en caviñena. Faits de Langues. Les Cahiers 1. 181-204.

Guillaume, Antoine. 2013. Reconstructing the category of "associated motion" in Tacanan languages (Amazonian Bolivia and Peru). In Kikusawa, Ritsuko and Lawrence A. Reid (eds.), Historical Linguistics 2011: Selected papers from the $20^{\text {th }}$ International Conference on Historical Linguistics, Osaka, 25-30 July 2011, 129 - 151. Amsterdam: Benjamins.

Guillaume, Antoine. 2016. Associated motion in South America: Typological and areal perspectives. Linguistic Typology 20(1). 81-177.

Koch, Harold. 1984. The category of 'associated motion' in Kaytej. Language in Central Australia 1: 23-34.

Lichtenberk, Frantisek. 1991. Semantic change and heterosemy in grammaticalization. Language 67(3): 475-509.

Lusekelo, Amani. 2010. Comparative study of the motion domain in Tanzanian Bantu languages. Kiswahili 73(1).

Maho, Jouni Filip. 2009. NUGL Online. The online version of the new updated Guthrie list, a referential classification of the Bantu languages. http://goto.glocalnet.net/mahopapers/nuglonline.pdf (29 December, 2016).

Muzale, Henry R.T. and Josephat M. Rugemalira. 2008. Researching and documenting the languages of Tanzania. Language Documentation \& Conservation 2(1). 68-108.

Nicolle, Steve. 2002. The grammaticalisation of movement verbs in Digo and English. Revue de Sémantique et Pragmatique 11. 47-67.

Nicolle, Steve. 2003. Distal aspects in Bantu languages. In Jasczolt, Kararzyna M. and Ken Turner (eds.), Meaning through language contrast, vol.2. 3-22. Amsterdam: Benjamins.

Nurse, Derek. 2008. Tense and aspect in Bantu. Oxford: Oxford University Press.

Persohn, Bastian 2017a. The verb in Nyakyusa: a focus on tense, aspect, and modality. Berlin: Language Science Press.

Persohn, Bastian 2017b. Locative and extra-locative clitics in Nyakyusa. Africana Linguistica 23. $151-165$. 
Schadeberg, Thilo C. and Mucanheia, Francisco U. 2000. Ekoti: the Maka or Swahili language of Angoche. Cologne: Köppe.

Schaefer, Ronald P. and Richard Gaines. 1997. Toward a typology of directional motion for African languages. Studies in African Linguistics 26(2). 193-220.

Seidel, Frank. 2007. The distal marker ka- and motion verbs in Yeyi. In Mietzner, Angelika and Yvonne Treis (eds.), Annual publications in African linguistics 5: Encoding motion. Case studies from Africa - In Memory of Ursula Drolc. 183 - 195. Cologne: Köppe.

Simons, Gary F. and Charles D. Fenning (eds.). 2017. Ethnologue: languages of the world. $22^{\text {nd }}$ edition. Dallas: SIL International.

Slobin, Dan I. 2004. The many ways to search for a frog: Linguistic typology and the expression of motion events. In Strömqvist, Sven and Ludo Verhoeven (eds.), Relating events in narrative, Vol. 2: Typological and contextual perspectives. 219-257. Mahwah: Erlbaum.

Stassen, Leon. 2013. Comparative constructions. In Haspelmath, Martin and Matthew S. Dryer (eds.), The world atlas of language structures online. Leipzig: Max Planck Institute for Evolutionary Anthropology. http://wals.info/chapter/121. (20 October, 2017)

Talmy. Leonard. 1985. Lexicalization patterns: Semantic structure in lexical forms. In Shopen, Timothy (ed.), Language typology and syntactic description: Grammatical categories and the lexicon. 57-149. New York: Cambridge University Press.

Talmy, Leonard 2000. Toward a cognitive semantics. Volume 2: Typology and process in concept structuring. Cambridge: MIT Press.

Thurmann, Robert C. Chuave medial verbs. Anthropological linguistics 17(7). 342-352.

TUKI. 2014a. English-Swahili dicationary / Kamusi ya kiingereza-kiswahili. Dar es Salam: Taasisi ya Uchunguzi wa Kiswahili $($ TUKI) = Institute of Kiswahili research, University of Dar es Salam.

TUKI. 2014b. Kamusi ya kiswahili-kiingereza / Swahili-Englisch dictionary. $2^{\text {nd }}$ edn. Dar es Salam: Taasisi ya Uchunguzi ya Kiswahili $(\mathrm{TUKI})=$ Institute of Kiswahili research, University of Dar es Salam.

Wilkins, David P. 1991. The semantics, pragmatics and diachronic development of 'associated motion' in Mparntwe Arrernte. Buffalo Papers in Linguistics 1: 207-257.

Wilkins, D. 2006 Towards an Arrernte grammar of space. In Levinson, Stephen C and David P. Wilkins (eds.), Grammars of space: explorations in cognitive diversity. 24-62. Cambridge: University Press.

Wilkins, David and Deborah Hill. 1993. Preliminary 'come' and 'go' questionnaire. In Stephen C. Levinson (ed.), Cognition and space kit (version 1.0): July 1993, 29-46. Nijmegen: Max Planck Institute for Psycholinguistics.

Wilkins, David P. and Deborah Hill. 1995. When "go" means "come": Questioning the basicness of basic motion verbs. Cognitive Linguistics 6(2/3). 209-259.

Wilson, Monica. 1963. Good company. A study of Nyakyusa age-villages. Boston: Beacon Press.

Bastian Persohn

persohn.linguistics@gmail.com
Submitted: 23 November 201

Accepted: 27 April 2018

Revisions: 1 May 2018 